\title{
A biodegradable polymeric system for peptide-protein delivery assembled with porous microspheres and nanoparticles, using an adsorption/infiltration process
}

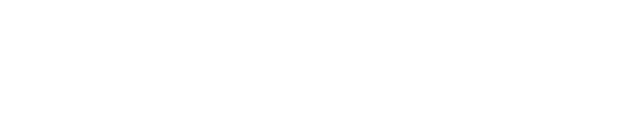

\section{Sergio Alcalá-Alcalá \\ Zaida Urbán-Morlán \\ Irene Aguilar-Rosas \\ David Quintanar-Guerrero}

Laboratorio de Investigación y Posgrado en Tecnología Farmacéutica, Facultad de Estudios Superiores Cuautitlán, Universidad Nacional Autónoma de México, Cuautitlán Izcalli, Estado de México, México
Correspondence: Sergio Alcalá-Alcalá Laboratorio de Investigación y Posgrado en Tecnología Farmacéutica, Facultad de Estudios Superiores Cuautitlán, Universidad Nacional Autónoma de México, Avenida $1^{\circ}$ de Mayo s/n,

Campo I, Cuautitlán Izcalli,

Estado de México, CP 54743, México

Tel +52 5556232065

Fax +52 5558938675

Email sekyaa@gmail.com

David Quintanar-Guerrero

Email quintana@servidor.unam.mx

\begin{abstract}
A biodegradable polymeric system is proposed for formulating peptides and proteins. The systems were assembled through the adsorption of biodegradable polymeric nanoparticles onto porous, biodegradable microspheres by an adsorption/infiltration process with the use of an immersion method. The peptide drug is not involved in the manufacturing of the nanoparticles or in obtaining the microspheres; thus, contact with the organic solvent, interfaces, and shear forces required for the process are prevented during drug loading. Leuprolide acetate was used as the model peptide, and poly(D,L-lactide-co-glycolide) (PLGA) was used as the biodegradable polymer. Leuprolide was adsorbed onto different amounts of PLGA nanoparticles $(25 \mathrm{mg} / \mathrm{mL}$, $50 \mathrm{mg} / \mathrm{mL}, 75 \mathrm{mg} / \mathrm{mL}$, and $100 \mathrm{mg} / \mathrm{mL}$ ) in a first stage; then, these were infiltrated into porous PLGA microspheres $(100 \mathrm{mg}$ ) by dipping the structures into a microsphere suspension. In this way, the leuprolide was adsorbed onto both surfaces (ie, nanoparticles and microspheres). Scanning electron microscopy studies revealed the formation of a nanoparticle film on the porous microsphere surface that becomes more continuous as the amount of infiltrated nanoparticles increases. The adsorption efficiency and release rate are dependent on the amount of adsorbed nanoparticles. As expected, a greater adsorption efficiency ( $95 \%)$ and a slower release rate were seen ( $20 \%$ of released leuprolide in 12 hours) when a larger amount of nanoparticles was adsorbed ( $100 \mathrm{mg} / \mathrm{mL}$ of nanoparticles). Leuprolide acetate begins to be released immediately when there are no infiltrated nanoparticles, and $90 \%$ of the peptide is released in the first 12 hours. In contrast, the systems assembled in this study released less than $44 \%$ of the loaded drug during the same period of time. The observed release profiles denoted a Fickian diffusion that fit Higuchi's model $\left(\mathrm{t}^{1 / 2}\right)$. The manufacturing process presented here may be useful as a potential alternative for formulating injectable depots for sensitive hydrophilic drugs such as peptides and proteins, among others.
\end{abstract}

Keywords: adsorption, biodegradable polymers, controlled release, nanoparticles, porous microspheres, peptide delivery

\section{Introduction}

Nanotechnology is the science that makes use of the new, modified, and unique properties of materials on a nanometric scale. As their size decreases, the new physical and chemical properties of the materials gain importance because of an increase in surface area, such that the quantum effects, surface properties, and large surface area-to-volume ratio all acquire dominance. Nanotechnology has been successfully applied in pharmaceutical technology to deal with a variety of challenges, such as low bioavailability, instability and low solubility of drugs, undesirable side effects, 
nontargeted delivery, low therapeutic effectiveness, inconstant blood levels, and frequent dosing. ${ }^{1,2}$

Over the past three decades, biomolecules like peptides, proteins, and deoxyribonucleic acid (DNA) analogs have been studied and proposed as therapeutic agents, owing to their high selectivity in the treatment of such diseases as cancer and enzymatic or genetic deficiencies. Advances in biotechnology have made possible the large-scale and efficient production of these molecules in quantities that are sufficient for research and the development of pharmaceutical products. ${ }^{3,4}$ However, peptides and proteins present some limitations in their usefulness as drugs. With respect to administration, they show instability in bodily fluids due to enzymatic susceptibility (proteolytic enzymes in the saliva, gastric juice, gut, skin, and lungs), whereas their large size and hydrophilicity impede access to target cells. Also, their rapid elimination from the body produces low therapeutic performance because of their short half-life and low bioavailability along the oral, transdermal, and pulmonary routes. This means that the parenteral route (muscular or intravenous injection) is the most suitable one for administration. ${ }^{5,6}$ In addition, the formulation techniques proposed, based on microencapsulation or freeze-drying, involve the use of organic solvents and interfaces that can provoke protein denaturation during microcarrier preparation. ${ }^{7}$ For these reasons, routes that present a minimum of biological and technological drawbacks for these molecules have been suggested. ${ }^{4}$

Technologies such as the PEGylation process, nanocarriers, and biodegradable polymeric micro- and nanoparticles have been proposed for peptide-protein delivery. In the case of the PEGylation process, the PEGylated proteins can generate anti-PEG antibodies that limit residence time in the bloodstream and the cross-linking may compromise peptide-protein stability. ${ }^{8}$ Previous studies have shown that the use of nanocarriers, such as polymeric nanoparticles and liposomes, provides in vivo stability, prolonged circulation time, improved solubility, targeted release, and fewer side effects to peptide-protein drugs compared with conventional formulations. ${ }^{3,6,9,10}$ Microspheres manufactured with natural and synthetic polymers have been studied as carriers for peptide-protein drugs because they protect the molecule during administration, regulate the blood levels, and exhibit a modified release that reduces repeated dosing. ${ }^{5,11-13}$ Finally, large, porous, biodegradable microspheres have been used as implant scaffolds in tissue engineering. ${ }^{14}$ However, the methods used to prepare the nanocarriers generally include polymerization processes, emulsification of natural or preformed polymers, and the subsequent elimination of the solvent, ${ }^{10}$ all of which contribute to creating an unfavorable environment for these drugs, whereas protein-loaded microspheres are commonly prepared by using a method called "double emulsion-solvent evaporation."15,16

Despite the advantages of using polymeric micro- and nanocarriers for peptide-protein delivery, there is an inherent instability in these molecules at each step of the manufacturing process. First, peptide-protein loading involves the use of organic solvents that generate changes in the physicochemical properties of the peptide-protein, while the interfaces in the emulsification stage may cause unfolding and aggregation through interfacial adsorption. Second, it has been shown that the high ionic strengths, shear forces, and interfaces involved in micro- and nanocarrier formation lead to biomolecule denaturation due to stress, since it is necessary to create a new emulsion by adding a nonsolvent for the polymer (eg, water) and, later, the organic solvent must be evaporated by stirring, reduced pressure, vacuum, or distillation. Finally, a drying step like lyophilization is required to remove the residual solvent, and observations have shown that peptide-protein degradation and aggregation are common events during this step. ${ }^{7,17}$ Various attempts have been made to prevent degradation during biomolecule formulation, such as by adding sugars, polyols, or other proteins (like albumin) to reduce the interface-protein ratio, using a nonaqueous process to avoid water/organic interfaces, reduce the homogenization time, and incorporate lyoprotectants. ${ }^{17}$

The main objective of this paper, then, is to propose and characterize a new carrier system for peptide-protein drugs; one that uses a simple immersion technique and an assembly method based on the infiltration of biodegradable polymeric nanoparticles into biodegradable porous microspheres obtained in separate stages; ${ }^{18}$ that is, without the peptide drug in these steps. Thus, it is suggested that the assembly process using adsorption protects the drug, since the peptide is not involved in the earlier procedures. The biodegradable polymer chosen was poly(lactide-co-glycolide acid) (PLGA) (see Figure 1), because it is a material widely used in the development of injectable and biocompatible drug delivery systems. Its properties, such as molecular weight, lactide/ glycolide ratio, and functional end groups, all affect drug release. ${ }^{19}$ The model peptide was leuprolide acetate, whose primary structure is 5-oxo-Pro-His-Trp-Ser-Tyr-Leu-LeuArg-Pro-NH- $\mathrm{C}_{2} \mathrm{H}_{5}$ (see Figure 2). This is a synthetic nonapeptide that is used as a luteinizing hormone-releasing hormone agonist in the treatment of hormone-dependent tumors, as in the cases of prostate and breast cancer, endometriosis, and adenomyosis. It is usually administered by the parenteral 
A<smiles>CCC(C)(O)OC(C)C(=O)COC(C)(C)C</smiles>

B<smiles>CCC(C)OC(C)C(=O)COC(C)(C)C(=O)COCC(C)=O</smiles>

Figure I Structure of poly(d,I-lactide-co-glycolide).

Notes: (A) Uncapped PLGA. (B) Capped PLGA.

Abbreviations: PLGA, poly(D,L-lactide-co-glycolide); m, lactide acid residue; $\mathrm{n}$, glycolide acid residue.

route owing to its poor oral bioavailability, short half-life, and instability in bodily fluids. ${ }^{20}$

\section{Materials and methods}

\section{Materials}

Poly(D,L-lactide-co-glycolide acid) (PLGA 50:50, DLG 4A, molecular weight 38,000), was obtained from Lakeshore Biomaterials (Birmingham, AL, USA). Poly(vinyl alcohol)

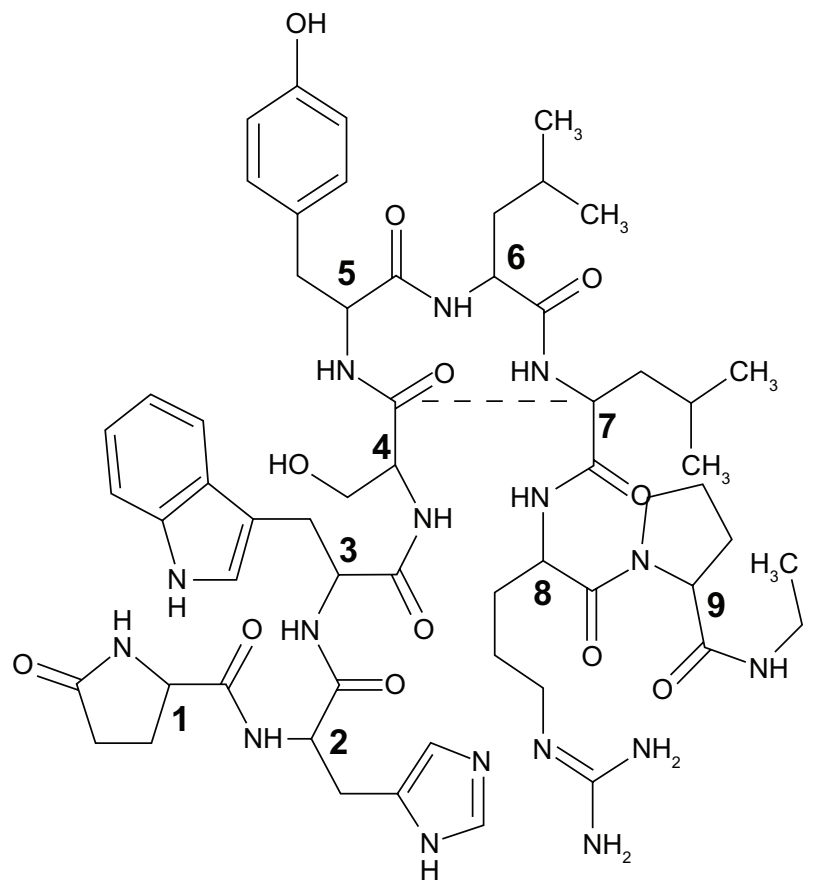

Figure 2 Structure of leuprolide acetate.
(PVAL), Mowiol ${ }^{\circledR}$ 4-88 (molecular weight 58,000) was purchased from Sigma-Aldrich (St Louis, MO, USA). Leuprolide acetate EP4, product PAADL01, batch SE-37733, was generously supplied by Probiomed ${ }^{\circledR}$ (Miguel Hidalgo, DF, Mexico). The dialysis tubing cellulose membrane, flat width of $10 \mathrm{~mm}$, was purchased from Sigma-Aldrich. Methylene chloride, ethyl acetate, acetonitrile, and methanol high-pressure liquid chromatography (HPLC) grade, phosphoric acid and mannitol were provided by J.T.Baker ${ }^{\circledR}$ Chemicals (Avantor Performance Materials, Center Valley, PA, USA). Ammonium carbonate, monobasic potassium phosphate, and sodium hydroxide were all supplied by Productos Quimicos Monterrey, SA (Monterrey, NL, Mexico). Triethylamine 99\% was acquired from Sigma-Aldrich. Distilled water was obtained from a RiOs ${ }^{\mathrm{TM}}$ distiller (EMD Millipore, Billerica, MA, USA).

\section{Preparation of polymeric nanoparticles}

Nanoparticles were prepared using the emulsification-solvent diffusion method described by Quintanar-Guerrero et al. ${ }^{10}$ First, a mixture of ethyl acetate and distilled water was saturated by manual agitation in a separatory funnel to achieve thermodynamic equilibrium; after 20 minutes, the phases were separated. Then, $400 \mathrm{mg}$ of PLGA 50:50 was dissolved in $20 \mathrm{~mL}$ of the organic phase (saturated ethyl acetate). The aqueous phase (saturated distilled water) was used to prepare a $5 \% \mathrm{w} / \mathrm{v}$ solution of PVAL. The organic phase was emulsified with $40 \mathrm{~mL}$ of the aqueous phase by stirring with a homogenizer (ULTRA-TURRAX ${ }^{\circledR}$; IKA ${ }^{\circledR}$ Works, Inc, Wilmington, NC, USA) at 11,000 rpm for 10 minutes. Afterward, $160 \mathrm{~mL}$ of distilled water without saturation was added to the emulsion to generate the diffusion of the organic solvent into the aqueous phase so that polymer aggregation would produce nanoparticles in suspension. In the next step, the organic solvent was removed under reduced pressure at $90 \mathrm{rpm}$ and $30^{\circ} \mathrm{C}$. The recovery of nanoparticles was carried out by centrifugation (Optima ${ }^{\circledR}$ LE- $80 \mathrm{~K}$; Beckman Coulter, Inc, Fullerton, CA, USA) at 20,000 rpm for 20 minutes. The nanoparticles were then resuspended in $3 \mathrm{~mL}$ of distilled water and washed three times. Finally, they were frozen and lyophilized (FreeZone 6; Labconco ${ }^{\circledR}$, Kansas City, MO, USA) at $50 \times 10^{-3} \mathrm{mbar}$ and $-40^{\circ} \mathrm{C}$ for 24 hours, with mannitol added as a cryoprotectant.

\section{Preparation of porous microspheres}

An adaptation of the modified "double emulsion $\left(\mathrm{W}_{1} / \mathrm{O} / \mathrm{W}_{2}\right)$ solvent evaporation" method proposed by Kim et $\mathrm{al}^{21}$ was performed to obtain porous microspheres sized $\leq 150 \mu \mathrm{m}$. The organic phase $(\mathrm{O})$ was prepared by dissolving $500 \mathrm{mg}$ of 
PLGA 50:50 in $8 \mathrm{~mL}$ of methylene chloride. After that, $50 \mathrm{mg}$ of $\mathrm{NH}_{4} \mathrm{HCO}_{3}$ (an agent that produces interconnected pores in the microspheres through gas generation) was placed in $5 \mathrm{~mL}$ of distilled water $\left(\mathrm{W}_{1}\right)$. The first emulsion was prepared with $2.5 \mathrm{~mL}$ of the $\mathrm{W}_{1}$ phase and $8 \mathrm{~mL}$ of the $\mathrm{O}$ phase, and stirred with a homogenizer (ULTRA-TURRAX ${ }^{\circledR} ;$ IKA $^{\circledR}$ Works, Inc) at $11,000 \mathrm{rpm}$ for 1 minute. This emulsion was then poured dropwise into $300 \mathrm{~mL}$ of a PVAL $0.5 \% \mathrm{w} / \mathrm{v}$ aqueous solution $\left(\mathrm{W}_{2}\right)$ to be reemulsified with a variable-speed agitator $\left(\mathrm{Caframo}{ }^{\mathrm{TM}}\right.$ Limited, Wiarton, Ontario NOH 2T0, Canada) at $250 \mathrm{rpm}$ for 4 hours in order to obtain porous polymeric microspheres and evaporate the organic solvent. Once the solvent had evaporated, the microspheres were recovered by filtration and rinsed three times with distilled water. Finally, they were frozen and then lyophilized (FreeZone 6; Labconco ${ }^{\circledR}$ ) at $50 \times 10^{-3}$ mbar and $-40^{\circ} \mathrm{C}$ for 24 hours, adding mannitol as a cryoprotectant.

\section{Characterization of polymeric nanoparticles}

To evaluate nanoparticle morphology, a few drops of an aqueous nanoparticle suspension were spread on a coverslip and dried at room temperature. Samples were mounted on a metal stub and coated with a thin gold film of about $20 \mathrm{~nm}$ in a vacuum chamber (Fine Coat Ion Sputter JFC-1100; JEOL, Tokyo, Japan) for 3 minutes at $1.2 \mathrm{kV}, 10 \mathrm{~mA}$, and 0.15 torr of pressure. The samples were then observed under scanning electron microscopy (SEM) (JSM-25 S II microscope; JEOL).

The laser light-scattering technique was used to determine the average size and polydispersity index of the nanoparticles using a submicron particle counter (N4 Plus; Beckman Coulter, Inc). Samples of the nanoparticle suspension were diluted with distilled water to achieve the light-scattering signal that fits the instrument's sensitivity (ie, particle counts per second). Measurements were performed at a $90^{\circ}$ fixed angle for 60 seconds at a temperature of $20^{\circ} \mathrm{C}$; the laser light wavelength was $678 \mathrm{~nm}(\mathrm{He} / \mathrm{Ne} 10 \mathrm{~mW})$. The batches were analyzed in triplicate $(n=3)$.

\section{Characterization of porous microspheres}

Dried microspheres were resuspended in distilled water and placed on a coverslip in the same way as described in the preceding section to analyze their morphology by SEM (JSM-25 S II microscope; JEOL). Shape, surface, and internal interconnected pores were characterized in terms of their size, porosity, and surface pore diameter by using image analysis. To measure surface pore diameter, 100 microspheres were analyzed in five different fields of view $(n=3)$. The image scale was used to measure mean pore diameter. With the use of a microsphere suspension in distilled water, the mean diameter, particle size distribution, and specific surface area of the microspheres were measured in three different batches, using a laser diffraction particle size analyzer (Mastersizer ${ }^{\circledR}$ 2000; Malvern Instruments, Malvern, UK).

\section{Adsorption studies of leuprolide onto microspheres and nanoparticles}

To evaluate the best leuprolide/microsphere ratio, several different amounts of peptide were adsorbed onto the surface of the microspheres. First, $10 \mathrm{mg}$ of dried microspheres was suspended in $1 \mathrm{~mL}$ of a $0.02 \mathrm{M}$ potassium phosphate buffer (pH 7.2). Subsequently, $0.5 \mathrm{mg}, 1 \mathrm{mg}, 2 \mathrm{mg}, 3 \mathrm{mg}$, and $4 \mathrm{mg}$ of leuprolide acetate was added to the aforementioned microsphere suspension, and the resulting samples were labeled as A, $\mathrm{B}, \mathrm{C}, \mathrm{D}$, and E, respectively. In this way, leuprolide/microsphere ratios of $5 \%, 10 \%, 20 \%, 30 \%$, and $50 \% \mathrm{w} / \mathrm{w}$ were reached. Afterward, each sample was gently stirred for 12 hours. The microspheres, with the adsorbed peptide, were recovered by filtration. The amount of leuprolide acetate was determined in the supernatant by HPLC (Agilent Technologies, Santa Clara, CA, USA), under the following chromatography conditions: P210 pump, 400 autosampler, 320 ultraviolet-visible detector (at $220 \mathrm{~nm}$ ), and C8 column $(250 \times 4.6 \mathrm{~mm}, 5 \mu \mathrm{m}$ particle size, Microsorb-MV, Agilent Technologies, Santa Clara, CA, USA). Finally, the mobile phase consisted of triethylamine solution (pH 3.0)-methanol-acetonitrile (70:5:25). The adsorption efficiency $(\% \mathrm{AE})$ was calculated by the difference between total and free peptide concentrations. All determinations were carried out in triplicate $(n=3)$.

To study the adsorption effect of leuprolide on the nanoparticles, the $\zeta$-potential of the nanoparticles adsorbed with increasing amounts of the peptide was determined, as follows: $100 \mathrm{mg}$ of dried nanoparticles were resuspended in $10 \mathrm{~mL}$ of a $0.02 \mathrm{M}$ potassium phosphate buffer solution, at $\mathrm{pH} 7.2(10 \mathrm{mg} / \mathrm{mL})$; then $2.5 \mathrm{mg}, 5.0 \mathrm{mg}, 7.5 \mathrm{mg}$, and $10 \mathrm{mg}$ of leuprolide was added to $1 \mathrm{~mL}$ of the previous suspension and subsequently stirred for 1 hour. The nanoparticle suspension with no peptide was set as the blank. The $\zeta$-potential of the dispersions was measured by dynamic light scattering using a Zetasizer ${ }^{\circledR}$ (Malvern Instruments) after appropriate dilution with the same buffer solution. Three replicates per concentration were analyzed $(n=3)$.

\section{Assembly of the systems by the adsorption/infiltration of nanoparticles into microspheres and peptide loading}

The process was carried out as follows: five systems, labeled 1 , 2, 3, 4, and 5, were prepared in triplicate. System 1 was 
assembled without nanoparticle adsorption, while systems 2, 3, 4 , and 5 were prepared by adding nanoparticle suspensions of $25 \mathrm{mg} / \mathrm{mL}, 50 \mathrm{mg} / \mathrm{mL}, 75 \mathrm{mg} / \mathrm{mL}$, and $100 \mathrm{mg} / \mathrm{mL}$, respectively. The nanoparticles were placed in a glass vial and resuspended in $1 \mathrm{~mL}$ of a $0.02 \mathrm{M}$ potassium phosphate buffer solution at pH 7.2 for 12 hours by magnetic agitation (Multistirrer; VELP Scientifica, Usmate, Italy). Afterward, $10 \mathrm{mg}$ of leuprolide were added simultaneously to each suspension. Agitation was continued for 1 hour more (systems 2, 3, 4, and 5). In brief, $100 \mathrm{mg}$ of porous biodegradable microspheres was dipped into each one of the systems and then placed under mechanical agitation for 1 additional hour (Water Bath Shaker; Reichert Technologies, Depew, NY, USA). For system 1, under the same conditions, only porous microspheres were immersed in $1 \mathrm{~mL}$ of the buffer solution for just 1 hour, where $10 \mathrm{mg}$ of leuprolide had been dissolved previously. All the systems were recovered by filtration and dried at room temperature. Figure 3 shows a general outline of the assembly process. The loading amount of leuprolide adsorbed into the systems was quantified by HPLC, as indicated above. Finally, the adsorption efficiency (\%AE) was calculated by using the following equation:

$$
\% \mathrm{AE}=\mathrm{W}_{\mathrm{AL}} / \mathrm{W}_{\mathrm{IL}} \times 100,
$$

where \%AE is the adsorption efficiency; $\mathrm{W}_{\mathrm{AL}}$ and $\mathrm{W}_{\mathrm{IL}}$ represent the amount adsorbed and the initial amount of leuprolide acetate, respectively. Finally, the supernatant was lyophilized, and the efficiency of the nanoparticles loaded into the microspheres was calculated by weight difference.

\section{Characterization of the assembled systems}

To examine the surface morphology of the systems obtained, samples were spread over a coverslip and treated as described above for SEM analysis (JSM-25 S II microscope; JEOL). All systems were characterized by differential scanning calorimetry (DSCQ10 calorimeter; TA Instruments, New Castle, $\mathrm{DE}, \mathrm{USA}$ ) to evaluate the interactions of their components. Calorimetric tests were performed on all the assembled systems (1-5), as well as on the individual components, including leuprolide acetate and PLGA polymer. Dried $2 \mathrm{mg}$ to $4 \mathrm{mg}$ samples were placed on aluminum pans and sealed hermetically. Scanning was carried out at temperatures between $5^{\circ} \mathrm{C}$ and $200^{\circ} \mathrm{C}$ with a $10^{\circ} \mathrm{C} /$ minute heating rate, under ultrapure nitrogen flux (50 mL/minute).

\section{In vitro peptide release}

Leuprolide release profiles were obtained for all the assembled systems (1-5): $60 \mathrm{mg}$ of each system was weighed directly in a prehydrated sack of dialysis cellulose membrane, whose length was $5 \mathrm{~cm}$. The leuprolide acetate in solution immediately crossed the cellulose membrane,

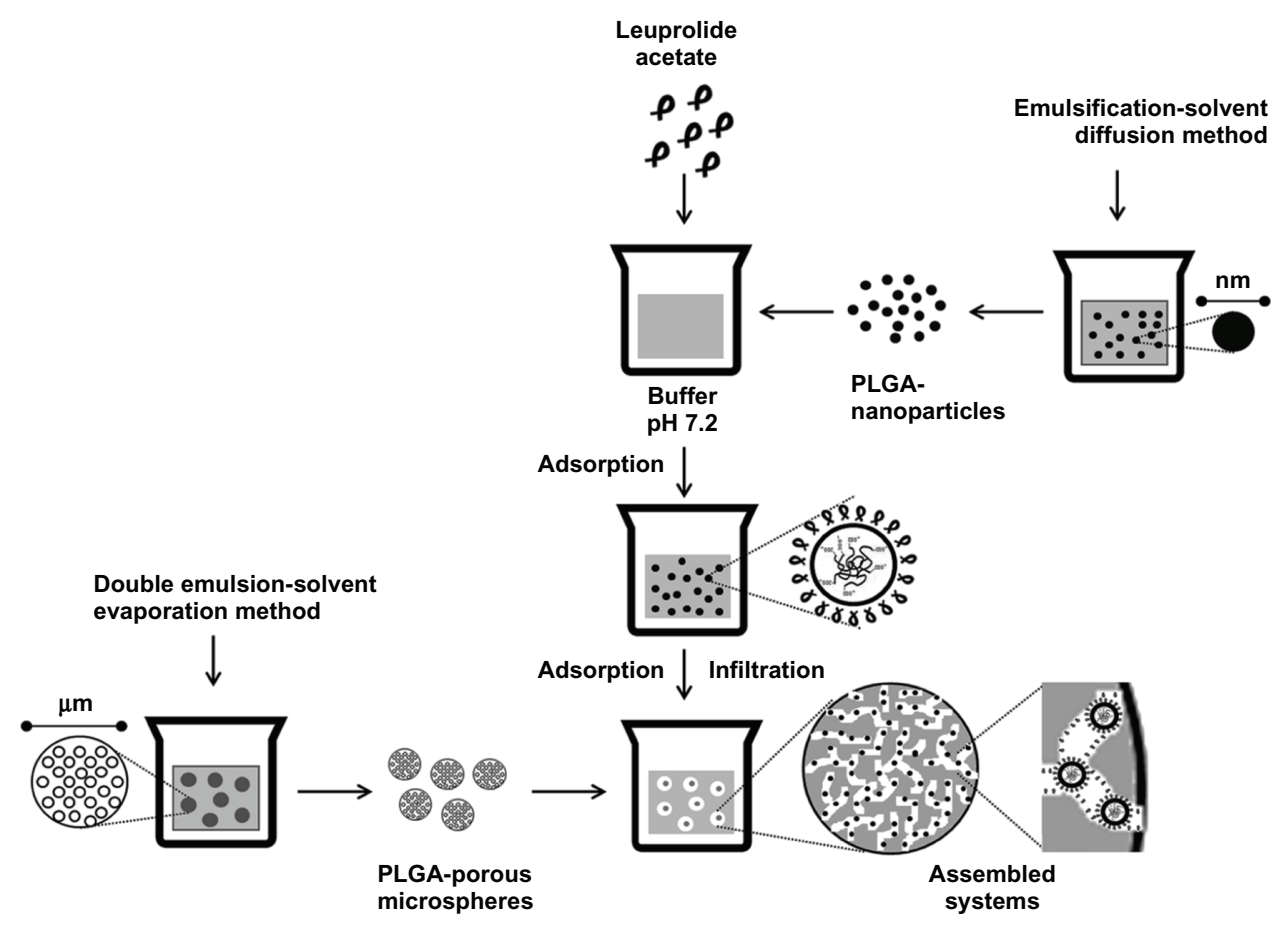

Figure 3 Manufacturing process of the assembled systems by adsorption/infiltration of polymeric nanoparticles into porous biodegradable microspheres. Abbreviation: PLGA, poly(D,L-lactide-co-glycolide). 
showing that the membrane does not limit or control peptide release. The sacks were dipped in $10 \mathrm{~mL}$ of a $0.02 \mathrm{M}$ potassium phosphate buffer at $\mathrm{pH} 7.2$ in a glass vial under "sink" conditions during the study (leuprolide concentration $\leq 250 \mathrm{mg} / \mathrm{mL}$ ), and transferred immediately to a thermostated bath at $37^{\circ} \mathrm{C}$, where they were shaken under the same agitation conditions as indicated in the description of the assembly of the systems. At predetermined intervals, $500 \mu \mathrm{L}$ was withdrawn from the release medium, and $500 \mu \mathrm{L}$ of fresh medium was added to the test vials. The amount of released leuprolide at each time point was determined by HPLC-ultraviolet at $220 \mathrm{~nm}$. All experiments were performed in triplicate $(n=3)$.

\section{Results and discussion}

\section{Acquisition and characterization} of polymeric micro- and nanoparticles

The well known emulsification-solvent diffusion method was used to prepare polymeric nanoparticles. ${ }^{10} \mathrm{SEM}$ showed solid, compacted, and spherical submicronic particles (see Figure 4). As expected, this method made it possible to obtain nanoparticles with a $267 \pm 3.8 \mathrm{~nm}$ mean size distribution and a polydispersity index of $0.07 \pm 0.01$. Nonstatistically significant differences were found in more than three prepared batches (analysis of variance [ANOVA] $P>0.05)$. These properties were suitable for carrying out the peptide adsorption procedure and the subsequent nanoparticle infiltration into porous microspheres. With respect to the microspheres, we produced porous structures by adapting the modified double emulsion-solvent evaporation technique proposed by Kim et al. ${ }^{21}$ The stirring velocity time, stabilizer (PVAL), and porogen concentration $\left(\mathrm{NH}_{4} \mathrm{HCO}_{3}\right)$ were all controlled in order to generate microparticles with properties adequate for the assembly process. As shown in Figure 5A, spherical porous microspheres with high porosity,

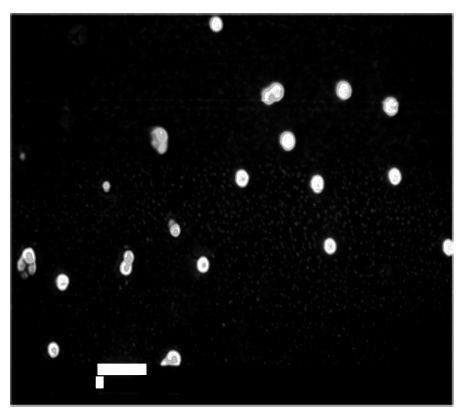

Figure 4 Scanning electron micrograph of polymeric nanoparticles of PLGA 50:50. Note: $B a r=I \mu \mathrm{m}$.

Abbreviation: PLGA, poly(D,L-lactide-co-glycolide).

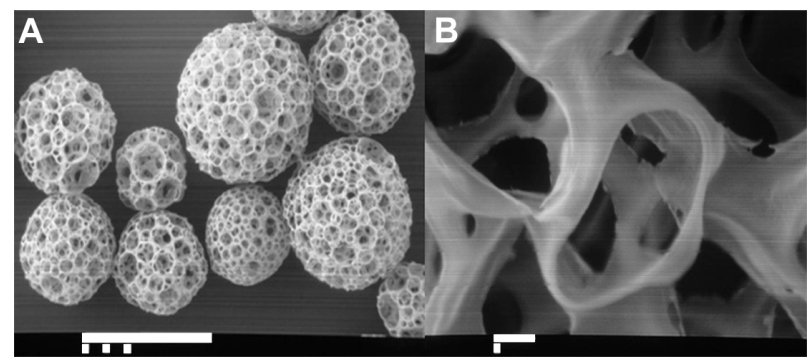

Figure 5 Scanning electron micrograph of porous microspheres of PLGA 50:50. Notes: (A) Microsphere structure, bar $=100 \mu \mathrm{m}$. (B) Pores in the internal matrix, bar $=I \mu \mathrm{m}$

Abbreviation: PLGA, poly(D,L-lactide-co-glycolide).

interconnecting pores, and a large surface were prepared. Their average size was found to be $78 \pm 32.9 \mu \mathrm{m}$, with a specific surface area of $6.67 \pm 0.13 \mathrm{~m}^{2} / \mathrm{g}$ in five batches with no significant differences among them (ANOVA $P>0.05$ ). This finding was confirmed by SEM. Regarding the size obtained, it is possible to inject microspheres by using conventional syringes (size $\leq 150 \mu \mathrm{m}$ ). ${ }^{2,223}$ Size is one of the parameters in microsphere manufacturing that can be controlled by varying the PVAL concentration in the continuous aqueous phase $\left(\mathrm{W}_{2}\right)$, or the agitation time and speed during manufacture. Pores are connected inside the internal matrix of the microspheres, providing a large surface area for adsorption (see Figure 5B). With the use of image analysis, the diameter of the exposed pores was determined, counting 100 pores in five fields of view. The mean diameter was approximately $8.1 \pm 4.1 \mu \mathrm{m}$, which is wide enough for the infiltration of nanoparticles $\leq 300 \mathrm{~nm}$ in size. No differences in the mean diameter of the exposed pores were found in the three batches (ANOVA $P>0.05$ ).

\section{Characterization of the adsorption process of leuprolide onto micro- and nanoparticles}

With the use of an aqueous immersion method, various amounts of leuprolide acetate were adsorbed onto porous microspheres in order to determine the leuprolide/microsphere ratio that showed the greatest adsorption efficiency. Ratios of leuprolide/microspheres of 5\%, 10\%, 20\%, 30\%, and $40 \% \mathrm{w} / \mathrm{w}$ were evaluated and the amount of adsorbed leuprolide was quantified. The results presented in Table 1 clearly show that there is a dependency on the leuprolide concentration in the adsorption process such that, as it increases, the amount of leuprolide adsorbed into the microspheres also increases; however, the adsorption efficiency reached a maximum when the $10 \% \mathrm{w} / \mathrm{w}$ leuprolide concentration was added (sample B). This finding could be 
Table I Adsorption of leuprolide onto microspheres and NPs

\begin{tabular}{|c|c|c|c|c|}
\hline \multicolumn{3}{|c|}{ \%AE onto microspheres } & \multicolumn{2}{|c|}{$\begin{array}{l}\zeta \text {-potential of NPs } \\
\text { adsorbed with } \\
\text { leuprolide }\end{array}$} \\
\hline Sample & $\begin{array}{l}\text { Adsorbed } \\
\text { leuprolide (mg) }\end{array}$ & $\% A E$ & $\begin{array}{l}\text { Peptide } \\
\text { (mg) }\end{array}$ & $\mathrm{mV}$ \\
\hline A & $0.141 \pm 0.001$ & $27.9 \pm 0.28$ & Blank $^{\mathrm{a}}$ & $-23.6 \pm 0.84$ \\
\hline B & $0.561 \pm 0.037$ & $54.3 \pm 3.56$ & 2.5 & $-19.8 \pm 1.23$ \\
\hline C & $0.612 \pm 0.072$ & $31.3 \pm 2.94$ & 5.0 & $-17.1 \pm 2.20$ \\
\hline$D$ & $0.698 \pm 0.053$ & $23.1 \pm 1.39$ & 7.5 & $-15.6 \pm 2.34$ \\
\hline E & $1.458 \pm 0.149$ & $36.3 \pm 2.59$ & 10.0 & $-|0.6 \pm 2.5|$ \\
\hline
\end{tabular}

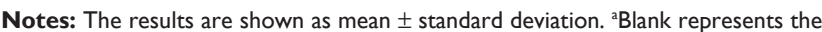
$\zeta$-potential of the polymeric nanoparticles without peptide adsorption.

Abbreviations: NP, nanoparticle; \%AE, adsorption efficiency.

related to surface saturation and the onset of the formation of adsorption layers. Similar results have been reported when serum albumin is adsorbed onto PLGA microspheres. ${ }^{16}$ Adsorption involves electrostatic and hydrophobic interactions, so physiochemical properties like $\mathrm{pH}$, ionic strength, and temperature play an important role in peptide-protein adsorption..$^{24,25} \mathrm{~A} \mathrm{pH}$ of 7.2 in the dipping solution creates an environment in which charged species exist; consequently, electrostatic interactions among the components are present in the adsorption process. ${ }^{20,26}$ The PLGA used in the present study has a free carboxylic end group, uncapped PLGA (Figure 1A), with a $\mathrm{pK}_{\mathrm{a}}$ of $\sim 3.8$, which is in the anionic form in the dissolution medium; whereas the basic amino acids of leuprolide, histidine (His-2), and arginine (Arg-8) acquire a cationic form, because they have isoelectric points of $\sim 7.8$ and $\sim 10.7$, respectively. These basic amino acids are exposed in the type $2 \beta$-turn peptide conformation that is stabilized by residues Ser-4 and Leu-7 in an aqueous phase (see Figure 2). ${ }^{27}$

The $\zeta$-potential was measured on polymeric nanoparticles of PLGA adsorbed with increasing amounts of leuprolide to test the electrostatic attraction in the adsorption process. Note in Table 1 that, as the amount of peptide increases, the $\zeta$-potential becomes more positive, suggesting that an electrostatic interaction is taking place. Luan and Bodmeier ${ }^{28}$ reported this interaction between leuprolide acetate and uncapped PLGA when they come into contact. In contrast, when PLGA with an esterified end group was used, capped PLGA (Figure 1B), there were no significant differences in the $\zeta$-potential $(-8.5 \pm 1.1 \mathrm{mV}$ for nanoparticles in suspension and $-9.1 \pm 1.4 \mathrm{mV}$ for nanoparticles with leuprolide acetate). The characteristics observed in these adsorption studies were achieved by adsorbing leuprolide acetate into microspheres and polymeric nanoparticles separately.

\section{Acquisition and characterization of the assembled systems by adsorption/infiltration}

The entrapment of leuprolide acetate was carried out by using a simple aqueous immersion method. Based on earlier results, a determined amount of leuprolide was used in the adsorption/infiltration process (ratio of $10 \% \mathrm{w} / \mathrm{w}$ leuprolide/ microsphere). The effect of different nanoparticle concentrations on adsorption efficiency was evaluated during the assembly process. Table 2 summarizes the drug loading, the adsorption efficiencies, and the nanoparticles loaded for all the assembled systems. System 1 represents the adsorption process with no infiltration of nanoparticles. Dependence between nanoparticle concentration and drug loading can also be seen, such that when there are more nanoparticles in suspension, the adsorbed amount of leuprolide and the load of nanoparticles within the assembled systems increase. This may be related to the large surface area and its availability for the adsorption process. The high shear forces, interfaces, and organic solvents commonly used in conventional microencapsulation are avoided during drug loading, so denaturation, aggregation, or degradation of the peptide is prevented, thus ensuring that the peptide is protected throughout the assembly process.

Nanoparticles can adsorb the peptide onto their surfaces as a first step, but they also infiltrate into microspheres in the same leuprolide solution, so microspheres are in contact with nanoparticles and the free peptide; hence, higher adsorption efficiency is found in systems with a larger number of adsorbed nanoparticles. The peptide can be adsorbed onto micro- and nanoparticle surfaces (see Figure 3). Since the nanoparticles and microspheres have the same chemical nature, leuprolide is loaded onto both surfaces. Nanoparticle adsorption was evidenced by SEM studies in which the images showed the formation of a nanoparticle film on

Table $2 \% A E$ of the assembled systems and their parameters for Higuchi's model $\left(\mathrm{t}^{0.5}\right)$

\begin{tabular}{llllll}
\hline System & $\begin{array}{l}\text { Adsorbed } \\
\text { leuprolide } \\
(\mathbf{m g})\end{array}$ & \%AE & $\begin{array}{l}\text { NPs } \\
\text { loaded } \\
(\mathbf{m g})\end{array}$ & $\mathbf{C C}^{\mathbf{a}}$ & $\begin{array}{l}\mathbf{K}_{\mathbf{H}} \\
\left(\mathbf{m i n u t e}^{-1}\right)^{b}\end{array}$ \\
\hline 1 & $1.9 \pm 0.18$ & $18.9 \pm 1.7$ & $-^{\mathrm{c}}$ & 0.984 & 0.042 \\
2 & $2.6 \pm 0.44$ & $25.3 \pm 4.1$ & $9.3 \pm 3.7$ & 0.980 & 0.021 \\
3 & $5.1 \pm 0.40$ & $47.1 \pm 1.6$ & $22.3 \pm 4.4$ & 0.994 & 0.015 \\
4 & $9.6 \pm 0.46$ & $94.6 \pm 3.4$ & $58.1 \pm 5.2$ & 0.987 & 0.014 \\
5 & $9.6 \pm 0.45$ & $94.9 \pm 4.5$ & $67.4 \pm 3.1$ & 0.988 & 0.014 \\
\hline
\end{tabular}

Notes: The results are shown as mean \pm standard deviation. ${ }^{\mathrm{a}} \mathrm{CC}=$ correlation coefficient $\left(r^{2}\right)$; ${ }^{b} \mathrm{~K}_{\mathrm{H}}=$ release rate constant, according to Higuchi's model; ' without nanoparticle infiltration.

Abbreviations: \%AE, adsorption efficiency; NP, nanoparticle. 

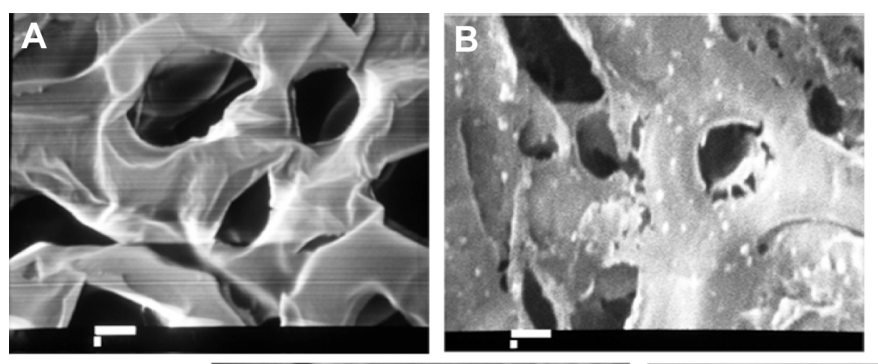
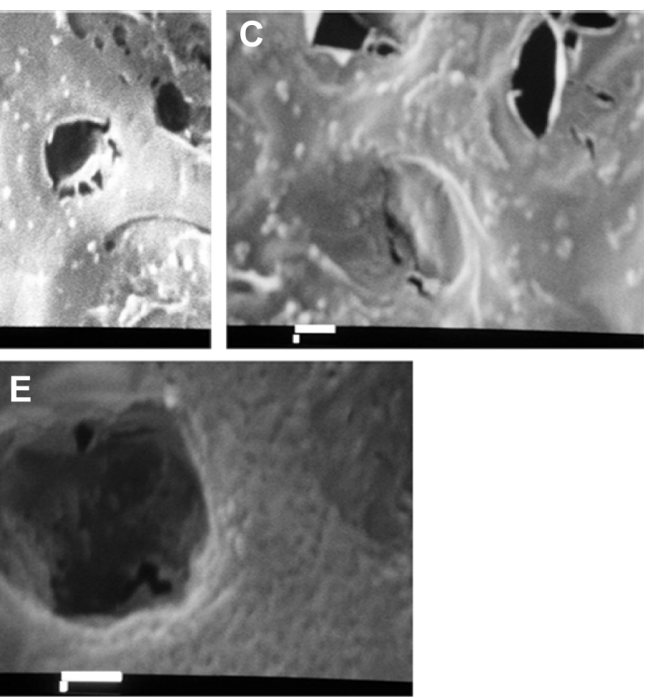

Figure 6 Scanning electron micrographs of the assembled systems with and without infiltration of polymeric nanoparticles. Notes: (A) System I: without nanoparticle infiltration. (B) System 2: with $25 \mathrm{mg} / \mathrm{mL}$ NPs. (C) System 3: with $50 \mathrm{mg} / \mathrm{mL}$ NPs. (D) System 4: with $75 \mathrm{mg} / \mathrm{mL}$ NPs. (E) System 5: with $100 \mathrm{mg} / \mathrm{mL}$ NPs. Bar $=1 \mu \mathrm{m}$.

Abbreviation: NPs, nanoparticles.

the microsphere surface as the adsorbed amount of nanoparticles increased (see Figure 6). As expected, the nanoparticle film was seen to cover the microsphere surface and to be more continuous in systems $4(75 \mathrm{mg} / \mathrm{mL}$ of nanoparticles) and $5(100 \mathrm{mg} / \mathrm{mL}$ of nanoparticles), which had larger amounts of loaded nanoparticles (see Table 2 and Figure 6D and E, respectively). A similar behavior was noted by RodríguezCruz et a ${ }^{18}$ using porous membranes and carbamazepine (a nonwater-soluble drug model). It is suggested that this nanoparticle film can act as a physical barrier for the release of the peptide, such that a continuous film could reduce the release rate more efficaciously than a discontinuous one.

In order to identify peptide distribution in the carrier, the physical state of the components, and any interactions between the peptide and the polymer (PLGA), calorimetric studies were performed for all systems. Figure 7 shows the differential scanning calorimetry thermograms of the assembled systems (1-5), pure PLGA (50:50), and pure leuprolide. Endothermic characteristic peaks are observed in the thermograms of pure leuprolide and pure PLGA polymer at $\sim 162^{\circ} \mathrm{C}$ and $\sim 46^{\circ} \mathrm{C}$, which correspond to leuprolide's melting point and the glass transition temperature ( $\mathrm{Tg}$ ) of PLGA, respectively. As shown in Figure 7, the endothermic peak of Tg PLGA $\left(44^{\circ} \mathrm{C}-46^{\circ} \mathrm{C}\right)$ can be identified in all systems, from 1 to 5 . However, the characteristic peak in the leuprolide thermogram is not visible in the thermograms that correspond to systems $1-5$, which suggests a molecular dispersion of the peptide throughout the assembled systems.

\section{In vitro release kinetics}

During the assembly process, five systems were prepared with different nanoparticle concentrations; their release profiles are shown in Figure 8. We found a burst effect within the first 30 minutes for all systems that was below $25 \%$ of the loaded

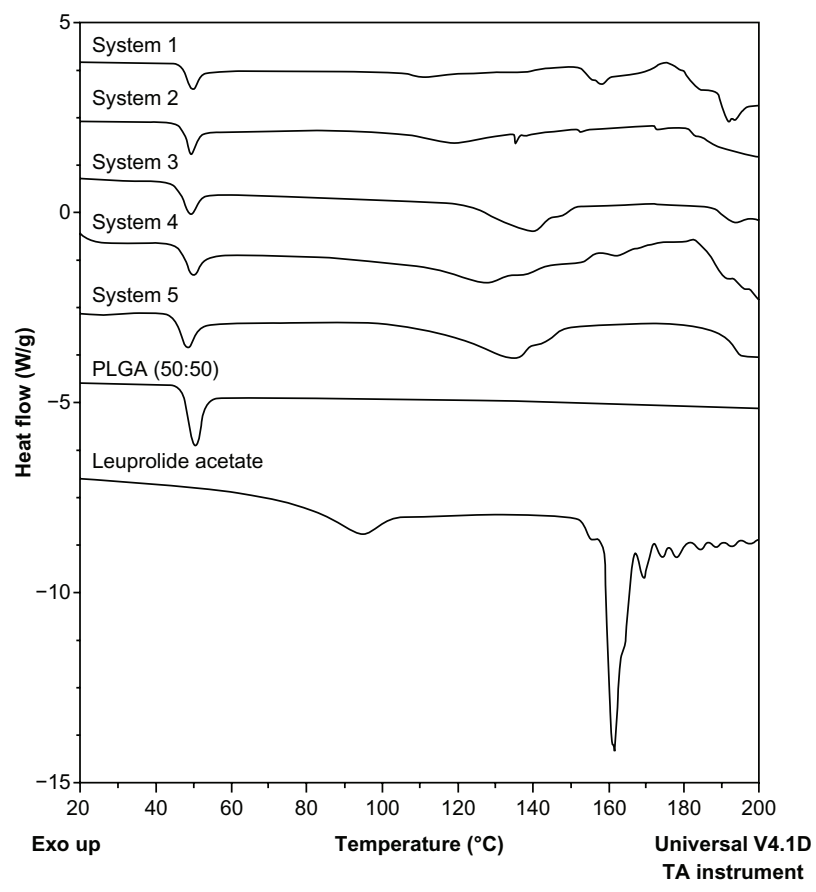

Figure 7 DSC thermograms, from top to bottom: systems I-5, pure PLGA (50:50) and pure leuprolide acetate.

Abbreviations: DSC, differential scanning calorimetry; PLGA, poly(D,L-lactide-coglycolide). 


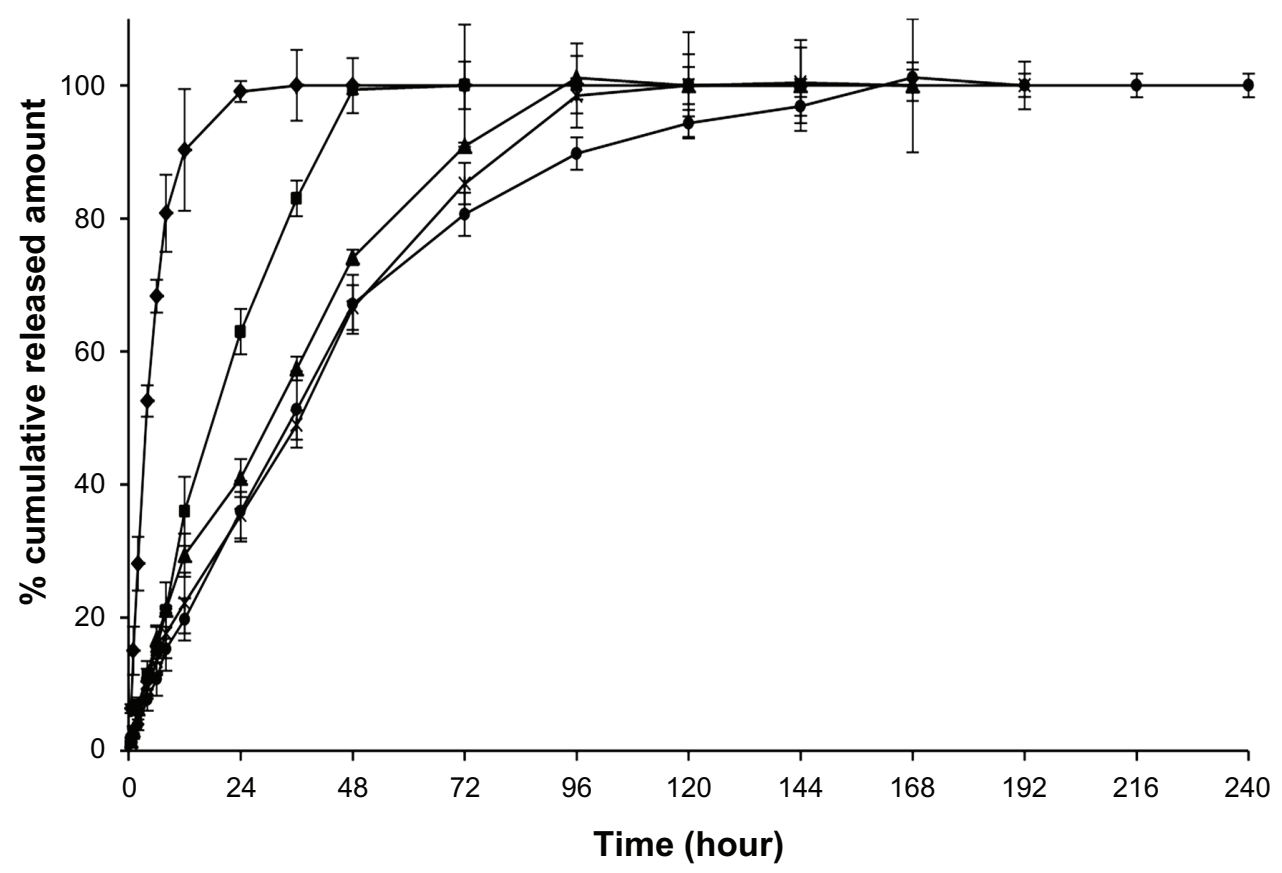

Figure 8 Release profiles of leuprolide acetate from the assembled systems.

Notes: (•) System I: without nanoparticle infiltration. (অ) System 2: with $25 \mathrm{mg} / \mathrm{mL}$ NPs. (A) System 3: with $50 \mathrm{mg} / \mathrm{mL}$ NPs. (*) System 4: with $75 \mathrm{mg} / \mathrm{mL}$ NPs. (•) System 5: with $100 \mathrm{mg} / \mathrm{mL} \mathrm{NPs}$.

Abbreviation: NPs, nanoparticles.

peptide. This finding can be associated with the leuprolide that was adsorbed onto the more superficial zone of the porous structure, since it is in immediate contact with the dissolution medium and thus enables the desorption process. . $^{16,21,29}$ Therefore, porosity and surface area play an important role in peptide release. However, at close to 12 hours, system 1 (without adsorbed nanoparticles) had released $90.3 \% \pm 9.1 \%$ of the peptide, whereas systems $2,3,4$, and 5 (with adsorbed nanoparticles) had released only $36.1 \% \pm 5.2 \%, 29.4 \% \pm 3.2 \%$, $22.2 \% \pm 4.6 \%$, and $19.8 \% \pm 3.2 \%$, respectively (see Figure 8 ). A higher release rate was found in the systems that contained a more discontinuous nanoparticle film on the microsphere surfaces, which may be due to the nanoparticle-leuprolidemicrosphere interactions generated during the assembly process, and to the continuity in the nanoparticle film, which appears to create a diffusion barrier and induce changes in the release rate. Thus, a controlled release is achieved when nanoparticles are adsorbed onto the porous microsphere surface (systems 2-5). Consequently, if the amount of nanoparticles increases, the release rate slows; this phenomenon could be explained by leuprolide entrapment between the surfaces and the nanoparticle film.

Based on the release profile models proposed, ${ }^{30}$ all the systems present a dominant Fickian diffusion mechanism because they are dependent on the square root of time $\left(t^{0.5}\right)$ (see Table 2 for the parameters). The release profiles fit Higuchi's model, ${ }^{30}$ as can be observed in Figure 9. This finding is explained by the porosity in the microsphere structure, which enables the diffusion process, since the pores allow water to penetrate into the system, forcing the peptide to diffuse out into the dissolution medium. According to these findings, diffusion of leuprolide throughout the matrix system was achieved.

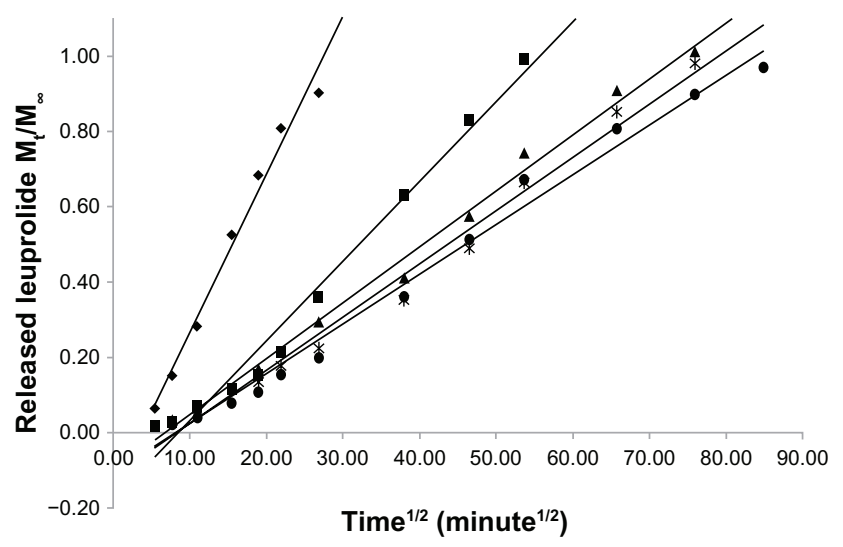

Figure 9 Higuchi's model for released leuprolide acetate from the assembled systems.

Notes: (•) System I: without nanoparticle infiltration. (ロ) System 2: with $25 \mathrm{mg} / \mathrm{mL}$ NPs. (A) System 3: with 50 mg/mL NPs. (*) System 4: with 75 mg/mL NPs. (•) System 5: with $100 \mathrm{mg} / \mathrm{mL}$ NPs. $M_{t} / M_{\infty}=$ amount released at time $\mathrm{t} /$ amount total released.

Abbreviation: NPs, nanoparticles. 


\section{Conclusion}

This work proposes a novel drug delivery system that was developed by adsorbing nanoparticles onto porous biodegradable microspheres by an infiltration process using an immersion method. Porous, biodegradable microspheres and polymeric, biodegradable nanoparticles were prepared by the double emulsion-solvent evaporation method and the emulsification-solvent diffusion method, respectively. They were obtained separately with no peptide interaction. The systems were assembled in short times by using an aqueous immersion method that prevented any contact between the peptide and the organic solvents, interfaces, and shear forces during drug loading to ensure the integrity of the peptide. Leuprolide acetate was entrapped in the polymeric matrix between the surfaces by the electrostatic interactions in the adsorption process. Its adsorption efficiency and release profiles showed a dependence on the amount of nanoparticles that infiltrated into the porous microspheres, such that a larger number of adsorbed nanoparticles led to a higher amount of loaded peptide and a slower release rate. The adsorbed nanoparticles created a film on the microsphere surface that appeared to act as a diffusion barrier, so the in vitro peptide release indicated that the systems assembled by nanoparticle infiltration reduced the burst effect, modified the release rate, and allowed a controlled release because of the formation of the film. The release rate slowed when the nanoparticle film was more continuous, thus prolonging the release period. Future work will need to consider determinations of conformational changes before and after adsorption in order to evidence peptide or protein integrity. The approach proposed in the present study can be used as an alternative in the formulation of peptide-protein drugs. These systems can be administered by different routes, including the parenteral route, as injectable depots, even for other biomolecules, such as proteins, enzymes, or DNA.

\section{Acknowledgments}

Sergio Alcalá thanks CONACyT for the grant he received (223443). The authors are grateful to Rodolfo Robles for his collaboration in the Scanning Electron Microscope studies and to DGAPA (project PAPIIT IN222411-3) for financial support of this work.

\section{Disclosure}

The authors report no conflicts of interest in this work.

\section{References}

1. Majumder DD, Banerjee R, Ulrichs CH, Mewis I, Goswami A. Nanomaterials: science of bottom-up and top-down. IETE Technical Review. 2007;24(1):9-25.
2. Williams $D$. The relationship between biomaterials and nanotechnology. Biomaterials. 2008;29(12):1737-1738.

3. Martins S, Sarmento B, Ferreira DC, Souto EB. Lipid-based colloidal carriers for peptide and protein delivery - liposomes versus lipid nanoparticles. Int J Nanomedicine. 2007;2(4):595-607.

4. Saez V, Hernández JR, Peniche C. Microspheres as delivery systems for the controlled release of peptides and proteins. Biotechnol Appl. 2007;24:98-107.

5. Sinha VR, Trehan A. Biodegradable microspheres for protein delivery. J Control Release. 2003;90(3):261-280.

6. Solaro R, Chiellini F, Battisti A. Targeted delivery of protein drugs by nanocarriers. Materials. 2010;3(3):1928-1980.

7. Lee ES, Kwon MJ, Lee H, Kim JJ. Stabilization of protein encapsulated in poly(lactide-co-glycolide) microspheres by novel viscous $\mathrm{S} / \mathrm{W} / \mathrm{O} / \mathrm{W}$ method. Int J Pharm. 2007;331(1):27-37.

8. Jain A, Jain SK. PEGylation: an approach for drug delivery. A review. Crit Rev Ther Drug Carrier Syst. 2008;25(5):403-447.

9. Soppimath KS, Aminabhavi TM, Kulkarni AR, Rudzinski WE. Biodegradable polymeric nanoparticles as drug delivery devices. $J$ Control Release. 2001;70(1-2):1-20.

10. Quintanar-Guerrero D, Fessi H, Allémann E, Doelker E. Influence of stabilizing agents and preparative variables on the formation of poly(D,L-lactic acid) nanoparticles by an emulsification-diffusion technique. Int J Pharm. 1996;143(2):133-141.

11. Ito F, Honnami H, Kawakami H, Kanamura K, Makino K. Preparation and properties of PLGA microspheres containing hydrophilic drugs by the SPG (shirasu porous glass) membrane emulsification technique. Colloids Surf B Biointerfaces. 2008;67(1):20-25.

12. Hiroaki O, Masaki Y, Toshiro H, et al. Drug delivery using biodegradable microspheres. J Control Release. 1994;28(1-3):121-129.

13. Wei W, Yuan L, Hu G, et al. Monodisperse chitosan microspheres with interesting structures for protein drug delivery. Adv Mater. 2008;20(12): 2292-2296

14. Shi X, Sun L, Jiang J, Zhang X, Ding W, Gan Z. Biodegradable polymeric microcarriers with controllable porous structure for tissue engineering. Macromol Biosci. 2009;9(12):1211-1218.

15. Rosca ID, Watari F, Uo M. Microparticle formation and its mechanism in single and double emulsion solvent evaporation. $J$ Control Release. 2004;99(2):271-280.

16. Sun L, Zhou S, Wang W, Li X, Wang J, Weng J. Preparation and characterization of porous biodegradable microspheres used for controlled protein delivery. Colloids Surf A Physicochem Eng Asp. 2009;345(1-3): 173-181.

17. van de Weert M, Hennink WE, Jiskoot W. Protein instability in poly(lactic-co-glycolic acid) microparticles. Pharm Res. 2000;17(10): 1159-1167.

18. Rodríguez-Cruz IM, Domínguez-Delgado CL, Escobar-Chávez JJ, Leyva-Gómez G, Ganem-Quintanar A, Quintanar-Guerrero D. Nanoparticle infiltration to prepare solvent-free controlled drug delivery systems. Int J Pharm. 2009;371(1-2):177-181.

19. Jain RA. The manufacturing techniques of various drug loaded biodegradable poly(lactide-co-glycolide) (PLGA) devices. Biomaterials. 2000;21(23):2475-2490.

20. Okada H. One- and three-month release injectable microspheres of the LH-RH superagonist leuprorelin acetate. Adv Drug Deliv Rev. 1997;28(1):43-70.

21. Kim TK, Yoon JJ, Lee DS, Park TG. Gas foamed open porous biodegradable polymeric microspheres. Biomaterials. 2006;27(2):152-159.

22. GeYB, Chen DW, Xie LP, Zhang RQ. Optimized preparation of daidzein-loaded chitosan microspheres and in vivo evaluation after intramuscular injection in rats. Int J Pharm. 2007;338(1-2):142-151.

23. O'Hagan DT, Jeffery H, Davis SS. Long-term antibody responses in mice following subcutaneous immunization with ovalbumin entrapped in biodegradable microparticles. Vaccine. 1993;11(9):965-969.

24. Li W, Li S. A study on the adsorption of bovine serum albumin onto electrostatic microspheres: role of surface groups. Colloids Surf A Physicochem Eng Asp. 2007;295(1-3):159-164. 
25. Tsai T, Mehta RC, Deluca PP. Adsorption of peptides to poly(D,Llactide-co-glycolide): 2. Effect of solution properties on the adsorption. Int J Pharm. 1996;127(1):43-52.

26. Mansour HM, Sohn M, Al-Ghananeem A, Deluca PP. Materials for pharmaceutical dosage forms: molecular pharmaceutics and controlled release drug delivery aspects. Int J Mol Sci. 2010;11(9):3298-3322.

27. Meyer JD, Manning MC, Vander Velde DG. Characterization of the solution conformations of leuprolide acetate. J Pept Res. 2002;60(3): $159-168$
28. Luan X, Bodmeier R. Influence of the poly(lactide-co-glycolide) type on the leuprolide release from in situ forming microparticle systems. J Control Release. 2006;110(2):266-272.

29. Singh S, Singh J. Phase-sensitive polymer-based controlled delivery systems of leuprolide acetate: in vitro release, biocompatibility, and in vivo absorption in rabbits. Int J Pharm. 2007;328(1):42-48.

30. Costa P, Sousa Lobo JM. Modeling and comparison of dissolution profiles. Eur J Pharm Sci. 2001;13(2):123-133.
International Journal of Nanomedicine

\section{Publish your work in this journal}

The International Journal of Nanomedicine is an international, peerreviewed journal focusing on the application of nanotechnology in diagnostics, therapeutics, and drug delivery systems throughout the biomedical field. This journal is indexed on PubMed Central,

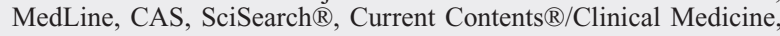

\section{Dovepress}

Journal Citation Reports/Science Edition, EMBase, Scopus and the Elsevier Bibliographic databases. The manuscript management system is completely online and includes a very quick and fair peer-review system, which is all easy to use. Visit http://www.dovepress.com/ testimonials.php to read real quotes from published authors.

Submit your manuscript here: http://www.dovepress.com/international-journal-of-nanomedicine-journal 